\title{
DO-IT-YOURSELF ON THE COSTA COLICA
}

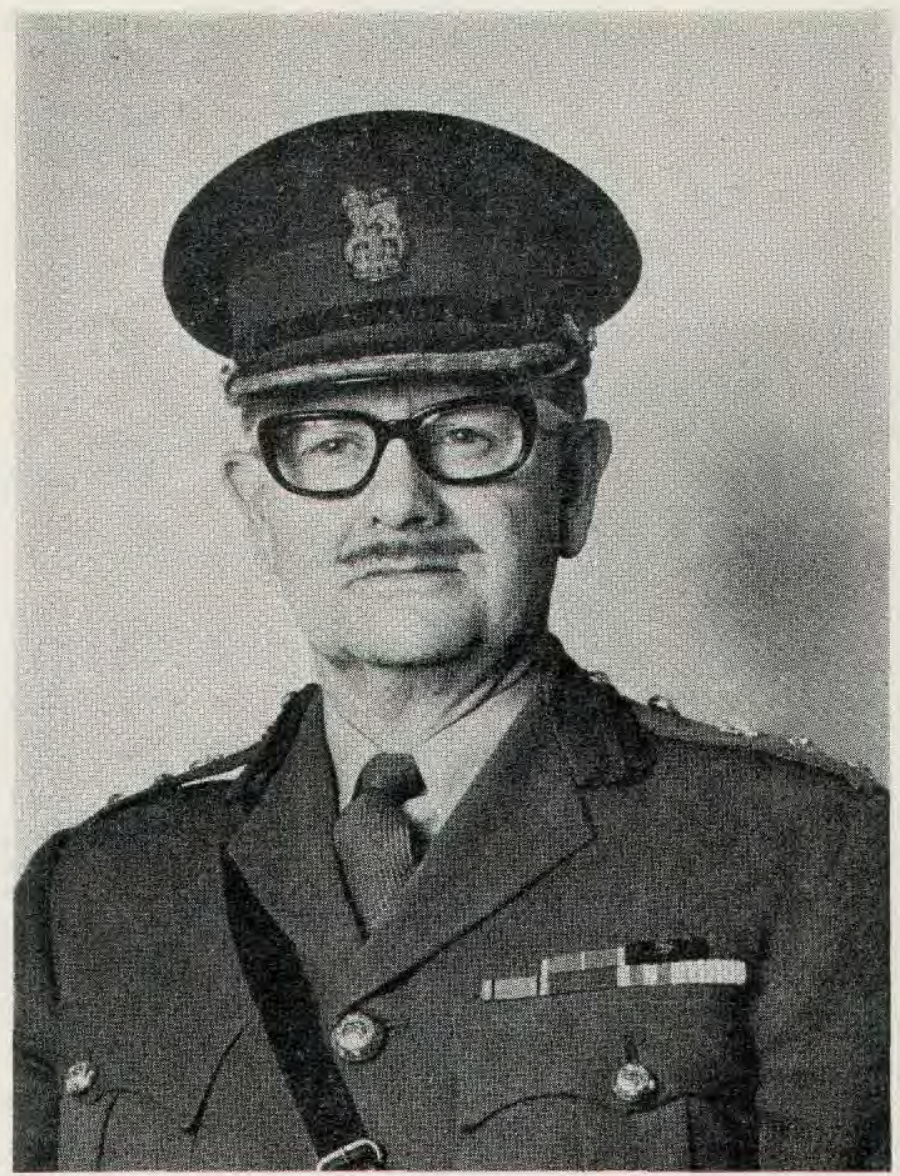

Colonel J. M. ADAM, O.B.E.

AN Army doctor who has suffered frostbite in the Antarctic, heat exhaustion in the Arabian desert and infestation in the Malayan jungle is probably the best person to advise on how to avoid the ills to which man abroad is heir.

The Royal Geographical Society thinks so. It has given its 1974 Patrick Ness award for exploration medicine to Colonel James M. Adam, Royal Army Medical Corps, for his book 'A Traveller's Guide to Health ". Colonel Adam says a lot of feeling went into the writing and he admits he now has no excuse for further overseas ailments.

The book-produced for the RGS -is accepted by explorers and the Army as an authoritative work; a guide to prevention, diagnosis and cure of everything from Aden tummy to the yaws. It is written in plain words as much for the package tourist to the Costa Colica as the expedition leader, and, in soft-back form, was a Hodder and Stoughton publication at $65 \mathrm{p}$, but is now out of print.

It was first published in 1966 and a revise will begin as soon as Colonel Adam, recently posted to Lubbecke, Germany, is joined by his wife who is also his secretary. 
He was presented with the award at the Royal Geographical Society's Annual Meeting on Monday 10 June 1974.

James Adam, aged 53, got his degree at Glasgow University and became Medical Officer to the 1st Royal Norfolks in 1946. His special interest is in endurance in extremes of climate, of which he has, of course, personal experience. He is a Fellow of the Royal Society of Medicine, a member of the expeditions committee of the RGS, of the Physiological Society, the Climatic Physiology Group, the Ergonomics Research Society, and the Exercise Physiology Group. He is the sole author of 25 publications, the joint author of 25 and he has made seven training films for the Army. He has a son and daughter and a Pyrrenean mountain dog called Hector, and he services his own car.

For Scotland: Colonel Adam was born in Ardrossan, Ayrshire, where his father was a headmaster. His widowed mother lives at Millburn Gardens, Largs.

\section{BOOK REVIEWS}

A History of the Army Medical Department. Lieutenant-General Sir NEIL CANTLIE. Edinburgh. Churchill Livingstone. Vol. 1. P. 519. Illustrations 10. Maps 16, Vol. 2. P.448. Illustrations 18. Maps 12. $£ 6.00$ per volume. Special Price to serving and retired members of the R.A.M.C. $£ 10 \cdot 50$ post free for both volumes.

Our Army Medical Service besides being one of the oldest of all Army Services has been distinguished by the complete absence of any detailed account of its origins and past. This unhappy distinction has now been removed for ever by the appearance of Sir Neil Cantlie's " History".

We are singularly fortunate that our history has been related by Sir Neil for not only is he a former DGAMS so that he has insight, understanding and sympathy with the problems which his predecessors faced, but he is a most conscientious and tireless seeker of source material and being the possessor of a most excellent prose style he has turned this material into an absorbing and smooth flowing narrative We can speak with knowledge as we have read his text three times - twice in MSS and once since publication, and enjoyed it on each occasion.

Above all Sir Neil brings such a balanced viewpoint to bear that his readers will accept his opinions and judgements unreservedly, and this naturally makes his work an authorative one.

Where both the professional historian and the general reader will be grateful to the author is in the statistics of sick returns and sick ratios which he has produced wherever records allow of this. These figures bring home with fearful clarity and force what havoc disease played in the past with our forces e.g. the loss of 100,000 men in the West Indies, a third of Wellington's Army incapacitated at one time, and so on. Another most valuable feature is that the references are printed at the end of each chapter so that they are very easily accessible. Add to this that there is an excellent summary of the Military operations of each campaign and the reader will realise how complete and self contained the History is. One of the sections of the book which will interest the reader most is that on the Crimean War to which a large part of Vol II is devoted. This coverage is more than justified as it was the Crimean War which brought the greatest volume of criticism of our Service and here for the first time the reader will read the other side of the story too long cast in darkness by the overbright light of Miss Nightingale's lamp as seen in retrospect.

All aspects of our story are dealt with-pay, status, promotion, conditions, medical supplies, transport etc. It is salutary to see how many of the problems our forbears faced are still with us.

Simple line maps cover virtually all the campaigns dealt with. These had to be produced on a no cost basis. We are glad to report that all except one have scales and even this map did have the scale on its original (we speak with knowledge as we were responsible for them!).

A more serious error by the publishers is the omission of page numbers for the maps which makes reference to them difficult. This omission should be remedied in any future editions.

To sum up then this is a splendid history fully worthy of its theme and because of its combination of scholarly research and excellent prose is fit to stand comparison with Oman and Fortesque and in consequence it will prove to be the definitive history as we cannot see how it can be bettered.

The author's reward - should he seek one-is the knowledge that as long as our Army exists his History will keep his name green and remembered.

Thank you Sir Neil.

A. MacLennan 